\title{
Educators' Perceptions of Peer Harassment among Rural Day Secondary Schools Pupils in Gweru, Zimbabwe
}

\author{
Nothabo Shoko ${ }^{1}$ \\ ${ }^{1}$ Faculty of Education, Midlands State University, Gweru, Zimbabwe \\ Correspondence: Nothabo Shoko, Faculty of Education, Midlands State University, Private Bag 9055, Gweru, \\ Zimbabwe. Tel: 263-7-7246-0992. E-mail: thaboshoko@googlemail.com
}

Received: July 4, 2012 Accepted: August 1, 2012 Online Published: October 18, 2012

doi:10.5539/ass.v8n13p80

URL: http://dx.doi.org/10.5539/ass.v8n13p80

\begin{abstract}
This study was carried out to explore educators' perceptions of peer harassment among rural day secondary school pupils in Gweru, Zimbabwe. The study was based on the assumption that peer harassment among secondary school pupils is a problem that needs to be prevented and so educators were viewed as critical players in the prevention of the problem hence it was important to understand their perceptions. The study was based on a sample of fifty five educators drawn from five randomly selected rural day secondary schools in Gweru district. The fifty five educators included five school heads who were purposively selected, twenty four female teachers and twenty six male teachers. All the teachers were selected using stratified random sampling. The main findings of the study were that all the educators agreed that nasty jokes, hitting and kicking and social exclusion were forms of peer harassment experienced by their pupils at school. However, their understanding of the effects of peer harassment on the victims' social development is underpinned by the different perceptions they have about the problem. While the majority of the educators perceived pupils who were subjected to such experiences by other pupils as having their human rights being violated, some of the educators thought that having pupils being subjected to such experiences was socially acceptable and it had positive benefits for the pupils' socialization. The findings also revealed that there were diverging views when it came to the educators' perceptions on spreading malicious rumors and sexual harassment among pupils. The divergence of views was based on gender divisions. While female educators perceived sexual harassment as a prevalent form of peer harassment among their pupils, male educators did not perceive it as being prevalent. Further variations in perceptions were also noted between teachers and school heads. While teachers thought peer harassment was a problem among pupils, three out of the five school heads thought teachers were viewing the dynamics of pupils' interactional processes using concepts that were alien to the Zimbabwean culture. The study concluded that there was a worrying diversity of perceptions among educators which could lead to varied responses in handling issues of peer harassment among pupils. Based on these findings, the study recommends that extensive studies be carried out to establish other stakeholders' perceptions of peer harassment so to enable authorities to come up with a shared conceptualization of the problem and so enhance the crafting of effective intervention strategies.
\end{abstract}

Keywords: educators, schools, pupils, peer harassment, bullying, social exclusion, extortion, social development

\section{Introduction}

Schools are not always the child friendly places that we assume them to be. Peer harassment is an aspect of school life that can go on in schools under cover or in full view of others. Emphasizing the need to ensure that schools are safe environments for children, De Wet (2009) argues that children's experiences at school are crucial to ensuring a smooth transition to adulthood as it is in schools that children negotiate relationships on which they build their self image. To ensure the full realization of this process schools must therefore provide safe environments for children to grow.

Peer harassment encompasses a variety of behaviors that are aimed at emotionally hurting somebody. Over the years society has become concerned about the various forms of harassment that go on in schools. The major points of concern are the subsequent effects that harassment has on teenage children hence the need to explore educators' perceptions of the problem. Some studies have used peer harassment to describe physical, verbal and other salient forms of abuse that go on among pupils of the same age. Verbal harassment is understood in the scope of actions like name calling ,making critical or threatening remarks as well as cruel criticism (Rusby, Forrester, Biglan and Metzler 2005).Other aspects of peer harassment also extend to bullying which 
encompasses exclusion, making unsettling or upsetting gestures, extortion as well as spreading malicious rumors about an individual, (Aluede,2011).According to Troope-Gordon (2010) pupils in American schools have reported receiving verbal slurs due to their appearance, weight or size. Others reported not going to school as a result of being harassed by peers. In this study, peer harassment is used to describe acts by one pupil or more that are directed at hurting another pupil.

In a report on a study of violence on children in Rwanda, Mitchelle and Kanyangara (2005), argue that some cultural and traditional virtues and practices tolerate some forms of violence against children and such views may influence educators' perceptions of peer harassment and inadvertently fuel the problem. De Wet (2009), further points out that the educators play a critical role in efforts to reduce pupil to pupil harassment. Prevention strategies of pupil to pupil harassment require the support of key persons, among them school personnel hence the need to explore the educators' perceptions of peer harassment among school pupils.

The problem can manifest itself in the social dynamics that obtain in the school. (Greef and Grobler, 2008) established that there was a higher rate of peer harassment among pupils than previous studies had established in South African schools. De Wet's study of educators' perceptions of bullying (which is a form of peer harassment) in the Free state in South Africa revealed that educators were aware that peer harassment is a serious problem in schools and that they were expected by society to prevent it. Aluede,(2006) concluded that there was a high prevalence of bullying in Nigerian schools. Swart and Bredekamp (2009) studied non physical forms of bullying among primary school girls in South Africa and they concluded that social exclusion and spreading malicious rumors about somebody were the most common forms of peer harassment among primary school girls in that country. Peer harassment occurs across social and cultural groups and Zimbabwean schools are not an exception. The Learn Without Fear Report (2011), points out that different social groups hold different perceptions of pupil to pupil harassment. The report argued that at one point bullying, which is a form of peer harassment, was acceptable to adults in many African cultural settings as it was a test for the victim's levels of resilience. Zindi (1994) reported that there was extensive bullying in boarding schools around Harare. The Zimbabwean of 14 October, 2009 also reported that peer harassment among pupils was a characteristic of most Zimbabwean schools. The same paper went on to point out that peer harassment among secondary school pupils was considered as a trivial issue among some societies in Zimbabwe, as it is sometimes perceived as a form of socialization.

The negative consequences of peer harassment are well documented (Troop -Gordon and Queenette,2010).The two researchers argue that educators 's perceptions' of peer harassment among pupils are important in that children may integrate their teachers reactions to peer harassment into their relational schemas, a move which may complicate the process of the building of relationships among individual children. Peer harassment may also contribute to problem behaviors that include drug abuse, suicidal ideation, externalizing problems, interpersonal difficulties and academic failure among many secondary school pupils,(Nishina, Juvonen and Witkow, 2005).Peer harassment among pupils leads to the development of tense learning environments and such environments may compromise learning as well as contribute to severe psychological distress among victims.

Peer harassment can interfere with a student's ability to learn and it can also have a range of debilitating effects on personality. The study looks at educators' perceptions of peer harassment among pupils at secondary school level because relationships among students are particularly important at this stage as adolescence is a stage during which children are defining themselves and establishing their self esteem,(De Wet 2009). It is important that educators help pupils to manage and nurture these relations. Peer harassment is deemed to be problematic as it contributes to children's self images and the social networks that they establish around themselves. Swart and Bredekamp (2009) further note that at this stage, children have a great need for intimacy and belonging. According to Troop Gordon and Quenette (2010) teachers may respond differently to peer harassment among pupils depending on the children involved. These reactions often result in numerous disciplinary problems and so this study was motivated by the desire to understand the educators' perceptions of peer harassment among their pupils.

Literature indicates that various studies have shown that peer harassment is prevalent among school pupils and that it wears many faces. Alluede (2011), De Wet (2009) and Zindi (1994), identify bullying in its various forms as peer harassment. These forms include physical bullying like frequent punching and kicking, taking a victim 's possessions without his or her consent, intentionally destroying a victim 's property for no apparent reason, frequent shoving or pulling of one's hair, intimidation and extortion of money. It also extends to verbal bullying which includes the use of demeaning language when speaking to or about the victim, name calling, racist or ethnic slurs, taunting and cruel criticism. Of late verbal harassment, has taken a new turn as it is now done through the internet or cell phone. Greef and Grobler (2008), term this form of harassment 'cyber' bullying or 'techno' bullying. According to Greef and Grobler (2008), in this kind of harassment the victim receives 
anonymous calls, messages or e-mails that are full of hate speech or insults directed at the victim. Even though some of these forms of harassment do not cause physical pain or harm to the individual, they leave an indelible mark on the emotions and the psyche of the victim hence they are a cause of concern to all stakeholders in education who desire to make schools safe havens for pupils.

Most cases of peer harassment at secondary school level are most lightly to be told to friends and on rare occasions, to family members. From the researcher 's experiences as a teacher, harassment among pupils sometimes occurs in school corridors and in class right under the educators' nose but these incidents might go unnoticed or deliberately ignored.

A lot of attention has been given to prevalence and effects of peer harassment among students as evidenced by the abundance of literature on the subject in American and European countries. However, not much has been done in Zimbabwe to understand educators' perceptions of peer harassment. This study focused on educators' perceptions of peer harassment among secondary school pupils in Gweru rural day secondary schools as an attempt to fill the void that exists on literature relating to educators' perceptions of pupil to pupil harassment in Gweru rural day secondary schools. The study is motivated by the belief that educators' perceptions have a lot to contribute towards the attempts to contain the problem. The study also assumed that educators' perceptions of the relational processes that arise because of peer harassment determined how they managed the problem in schools. The guiding question for the study was: How do educators perceive pupil to pupil harassment among pupils in Gweru rural secondary schools?

\subsection{Significance of the Study}

The researcher is of the conviction that educators should form the core of any prescriptions aimed at fighting peer harassment so it is important to explore their mental representations of peer harassment. Findings from this study can be linked to the strategies that they may employ to minimize the problem. This study will give a voice to the marginalized rural school populations. The study is also significant in that it will 'open' the stake holders' eyes to perceptions of educators on pupil to pupil harassment in schools. The findings will also help educators at school level to manage discipline from an informed position. The study will also help educators to reflect on some of their responses to observed or reported peer harassment among pupils in their schools. Understanding educators perceptions of peer harassment among pupils will also awaken other people's 'senses' to the existing relational dynamics among pupils so that concerted efforts can be made by all concerned to help both the victims of harassment and the perpetrators of peer harassment. Findings of this study will lay a foundation for further studies that will focus on comparing educators' perceptions of peer harassment among pupils and the intervention strategies they adopt in the classroom to minimize pupil to pupil harassment.

\subsection{Statement of the Problem}

The dynamics of pupil to pupil relationships in school have been known to determine individual pupils' disposition to school and to contribute to their personal behavior in many ways,( Troope- Gordon and Quenette 2010).The researcher 's interactive experience with pupils and teachers as a secondary school teacher led to the conclusion that peer harassment is a serious problem which most educators choose to ignore. The Zimbabwean media has written stories of children who have dropped out of school as a result of being constantly harassed by their peers. However, there is some unsettling silence on the voice of the educators with regards to their perceptions of peer harassment in most of the literature that relates to the problem in Zimbabwe in particular. Consequently, the current research aimed at exploring the educators' perceptions of peer harassment among Gweru rural day secondary school pupils.

\subsection{Delimitation of the Study}

The study was carried out in Gweru rural district schools that are registered with the Ministry of Education Sports and Culture. The Midlands province of Zimbabwe is divided into eight administrative districts (Ministry of Education Sport and Culture Schools Directory 2010) and Gweru district is one of them. Studying all the educators' perceptions of pupil to pupil harassment in all the schools in the province would be a difficult and unattainable task, so Gweru District which is more accessible to the researcher was chosen. Gweru district is further divided into two kinds of schools, namely Gweru rural and Gweru urban schools. This study was concerned with understanding educators' perceptions of pupil to pupil harassment in rural day secondary schools The main motivation for focusing on rural day secondary schools was that in the researcher's view, these schools tend to be marginalized by most researchers who often choose to focus on urban schools because of their accessibility to them. There are twenty eight rural day secondary schools and only five were purposively selected for the study. Boarding schools in the district were excluded because they fall under a different category of schools and their school cultures differ immensely from those of rural day secondary schools since they enroll 
pupils and recruit educators from a diversity of social backgrounds dependent on the guidelines dictated to them by their responsible authorities. Including boarding schools in this study would distort the views of other educators in rural day secondary schools as the two groups of educators do not share similar experiences, hence the exclusion of the former.

\section{Research Methodology}

This study was situated within the interpretive paradigm .Grix (2010) posits that the fundamental assumption of the interpretive paradigm is that the world does not exist independently of our knowledge of it and so any study that concerns itself with the social world should aim at understanding the way people construct their reality. This implies that any attempt to study the school as a social world should focus on 'unpacking' the meanings that the inhabitants of that of that school have about the various phenomena that surrounds them. In this study, the attempt was to unpack educators' perceptions of peer harassment among their pupils. Educators' perceptions of pupil to pupil harassment can be best understood by interpreting the mental conceptions that they hold about the forms of peer harassment experienced by pupils in Gweru rural day secondary schools. To explore the educators' perceptions in this study, two sets of instruments were administered to two different sub samples of the population. One sub sample of the educators responded to self administered questionnaires while the other sub sample responded to interviews. The two sets of data were analyzed for common as well as divergent views. From the views that emerged, interpretations of the educators' perceptions were then made. The findings were then presented in descriptive form with the aid of tables.

\subsection{Population and Sampling Techniques}

The population comprised of all the teachers and school heads in the five selected Gweru rural day secondary schools. The sample was made up fifty teachers ( 24 females and 26 males) and five school heads. Stratified random sampling was used to select the teachers while school heads were purposively selected on the basis of their administrative posts. Stratifying the sample of teachers ensured a fair representation of both sexes. Once permission was granted by the authorities to the researcher to carry out the study, she proceeded to make appointments with the school heads to seek their permission and that of the teachers to be included in the study. After permission had been granted, the researcher asked the school heads to provide a list of the names of all the teachers from which a sample was drawn using stratified random sampling.

\subsection{Instruments}

Teachers responded to a questionnaire while the school heads responded to face to face interviews. Using a questionnaire for teachers was appropriate as these could be administered in the school on the day the researcher was carrying out an interview with the school head. The arrangement also gave the teachers ample time to complete the questionnaires while the researcher was engaged in an interview with the head of the school. The researcher was then able to personally collect the questionnaires and so ruled out any possibility of questionnaires not being returned. The questionnaire for teachers was divided into three sections with section A being an open ended question that asked them to list the forms of peer harassment that existed among pupils in their schools, section B was a closed question that asked teachers to rank given forms of peer harassment among pupils in order of the frequency of their occurrence where 1 implied most frequent, 2 frequent, 3 sometimes and 4 once in a while. The forms that teachers had to rank were derived from existing literature on peer harassment among school pupils. Section $\mathrm{C}$ of the questionnaire was an open ended item which tried to determine how teachers perceived pupil to pupil harassment and to establish why they held those perceptions.

School heads responded to face to face interviews. These were conducted in their offices because it was convenient for the respondents. The main thrust of the interview was to establish the school heads' perceptions of peer harassment among school pupils. The views of the school heads were important for this study because their perceptions and attitudes set the tone of the school .Each interview lasted twenty five minutes.

\subsection{Data Analysis}

Data from questionnaires were analyzed manually using descriptive techniques .The frequency of the responses to sections A and B was computed into percentages. Responses to section C were grouped into categories and these were also converted to percentages. Interview responses were manually transcribed and common themes were generated from the transcriptions. These were then used to interpret the educators' perceptions of peer harassment. 


\section{Results}

\subsection{Questionnaire Responses from Teachers}

The first part of the questionnaire asked teachers to indicate whether they were male or female in the spaces provided. This was important as it allowed the researcher to analyze the responses according to the sex of the respondents in order to establish whether certain responses were peculiar to a particular sex. Teachers were then asked to indicate the forms of pupil to pupil peer harassment that existed in their schools by placing a tick against given behaviors that pupils normally subjected one another to at school. The behaviors were derived from existing literature on peer harassment among pupils. Table 1 shows the teachers' responses.

Table 1. Teachers perceptions of forms of peer harassment among school pupils $n=50$

\begin{tabular}{lll}
\hline Form & Frequency & Percentage frequency \\
\hline Nasty jokes & 50 & $100 \%$ \\
Hitting and Kicking & 50 & $100 \%$ \\
Social exclusion & 44 & $88 \%$ \\
Extortion & 34 & $68 \%$ \\
Spreading malicious rumours & 30 & $60 \%$ \\
Sending anonymous messages and calls & 20 & 40 \\
Sexual harassment & 10 & $20 \%$ \\
\hline
\end{tabular}

The responses on table 1 indicate that the most common forms of peer harassment among school pupils include making nasty jokes about a school mate, sending anonymous cell phone messages to victims, spreading malicious rumors and extorting money or property from victims. Sexual harassment was indicated as a form of harassment by only $20 \%$ of the respondents.

Responses on forms of peer harassment were further analyzed according to the sex of the respondents in order to establish whether teachers' perceptions on forms of peer harassment among pupils differed according to sex. Results are presented on table 2.

Table 2. Teachers' responses on forms of harassment according to sex

\begin{tabular}{lllll}
\hline Forms & Males & \%responses & Females & \%responses \\
\hline Nasty Jokes & 26 & 100 & 24 & 100 \\
Hitting and kicking & 26 & 100 & 24 & 100 \\
Social exclusion & 20 & 76 & 24 & 100 \\
Extortion & 14 & 53.84 & 16 & 66.66 \\
Spreading malicious rumors & 5 & 19.23 & 15 & 57.69 \\
Sending anonymous calls and messages & 10 & 38.46 & 0 & 41.66 \\
Sexual harassment & 0 & 0 & 10 & 41.66 \\
\hline
\end{tabular}

The results on table 2 indicate that male and female teachers have varying perceptions on the forms of peer harassment among pupils. While $41.66 \%$ of the female teachers thought sexual harassment was one of the forms of harassment that existed among pupils, male teachers did not think the same. Another notable divergence based on perceptions according to sex was noted where $19.23 \%$ of the male teachers perceived spreading malicious rumors as a form of peer harassment as opposed to $57.66 \%$ of females who shared similar perceptions.

Teachers were also asked to rank forms of peer harassment they had listed in response to item 1 of the questionnaire in order of the frequency of occurrence in their schools and the results are presented on table 3 .

Table 3. Teachers' perceptions of the prevalence of peer harassment among pupils in rank order $n=50$

\begin{tabular}{llll}
\hline Form & Rank & Frequency of responses & Percentage Frequency \\
\hline Nasty Jokes & 1 & 50 & $100 \%$ \\
Hitting and kicking & 2 & 46 & $92 \%$ \\
Social exclusion & 3 & 44 & $88 \%$ \\
Extortion and spreading malicious rumors & 4 & 35 & $70 \%$ \\
Sexual harassment & 5 & 10 & $20 \%$ \\
\hline
\end{tabular}


Table 3 indicates that nasty jokes, hitting and social exclusion were ranked numbers one two three respectively. All the respondents concurred that making nasty jokes about a victim was the most common form of peer harassment among pupils .However only $20 \%$ of the respondents indicated sexual harassment as a common form of harassment among pupils. Sexual harassment was ranked number five.

The study also tried to determine what teachers thought about peer harassment in their schools and so they were asked to respond to a two part question where in the first part they were to indicate whether the problem of peer harassment was a very serious problem, minor problem or not a problem at all in the school. In the second part of the question teachers were asked to justify their stance. $65 \%$ of the respondents said it was a very serious problem in their schools, $25 \%$ said it was a minor problem while $10 \%$ said it was not a problem at all. Table 4 gives some of the reasons the teachers gave for their responses. The $65 \%$ who perceived peer harassment as a problem were of the conviction that such behavior was a violation of children's rights. It was however interesting to note that those who thought it was a minor problem were convinced that peer harassment among pupils had some positive impact as they argued that it gave children the opportunity to learn that relationships were not always smooth while those who did not perceive it as a problem argued that they all went through the same experiences and so they did not think it should be a problem to their students now.

Table 4. Teachers' justification of their perceptions

\begin{tabular}{lll}
\hline SERIOUS 65\% & MINOR 25\% & NOT A problem 10\% \\
\hline $\begin{array}{l}\text { It violates the rights of other } \\
\text { children }\end{array}$ & Most pupils can handle it. & $\begin{array}{l}\text { No one ever reports that they are } \\
\text { being harassed. }\end{array}$ \\
$\begin{array}{ll}\text { It disturbs pupils learning } & \begin{array}{l}\text { Pupils need to learn that relations are not } \\
\text { always smooth. }\end{array}\end{array}$ & $\begin{array}{l}\text { It is part of growing up, we all } \\
\text { went through that. }\end{array}$ \\
$\begin{array}{l}\text { It impacts negatively on social } \\
\text { relations }\end{array}$ & $\begin{array}{l}\text { It only becomes a problem if somebody } \\
\text { gets injured. }\end{array}$ & \\
\hline It disrupts discipline & &
\end{tabular}

3.2 Responses from Interviews with School Heads

School heads responded to interviews that tried to establish their perceptions of pupil to pupil harassment. In response to forms of pupil to pupil harassment that existed in their respective schools, school head A had this to say:

School Head A: Well the most prevalent form of peer harassment among pupils is cracking nasty jokes about the victim.

School head B said: Uhm--- well the most common form of harassment is that of pupils who make jokes that are aimed at demeaning others.

School head C said: Pupils sometimes say very nasty things to one another.

School head D: Children can be really cruel to each other. They can really have a

School Head E said: Pupils do not harass each other. All they do is to engage in rough play and in my view that is not harassment. But is that an issue really?

When probed further to explain why he thought rough play was not an issue he said: In our culture as children grow they are expected to play rough as this is viewed as a necessary part of socialization. No parent wants their child to be a cry baby so the kind of rough interaction they sometimes engage in is supposed to make them tough.

Concurring with School head E's view, School head D retorted: Ah, the word harassment is new in our vocabulary. This is a western concept that is linked to this talk about children's rights.Our children are brought up under different circumstances. Fighting and saying nasty words to each other is acceptable as long as they do not use vulgar language.

The researcher also wanted to find out whether these school heads tried to help those pupils who reported that they were being harassed and school head B said: Yes I do. I make sure I train pupils to respect one another and to feel for each.

School head A said: We are expected as educators to see to the safety and comfort of children under our care but that does not stop them from harassing each other.I do not expect pupils to be reporting on such issues because these are adolescents and they should be able to deal with problems in their relationships.

School head C said: Such cases are uncommon. I am sure I would urge who ever reports that they are being 
harassed to be tough and stand up for themselves because as adults we are not always there to fight their battles, so they should learn to fight for themselves.

School head E said: There is no such thing as harassment among pupils.

The school head would not be drawn to say how he would handle reports of peer harassment in his school as he categorically stated that peer harassment did not exist in his school.

Asked what they had to say about teachers who thought peer harassment among pupils was a serious issue, school heads A and B all shared the view that peer harassment was indeed a serious problem. School head B further retorted: There is need for us educators to come up with strategies to address the problem. We need to combine our efforts to address the issue from all angles.

School head C said: Ah well today's teacher has different perceptions from yester year's teacher. Children should be taught to stand up for themselves and not to be taught to be whining all the time. When we grew up we were beaten up by other children and we dared not talk about it to adults because it would put us in bad light .In my opinion children who claim that they are being harassed have not been brought up the African way.

School head E said: I urge our teachers who are in full charge of the growth of our children to relook some of the teachings that are alien to our culture. I do not see anything wrong with boys touching girls'breasts because that in our culture is part of the process of courtship which they call dating today. Not everything that is practiced in our culture is barbaric. We need to be critical of some of these issues.

\subsection{Discussion of Results}

The study has established that educators perceive pupil to pupil harassment as being common in their schools. The teacher educators also concurred that pupils harassed each other both verbally and physically. They indicated that making nasty comments, hitting and kicking were the most common forms of pupil to pupil harassment. This is in line with international and local perceptions of educators' views of forms of peer harassment among pupils (De Wet 2009,Greef and Grobler ,2008 Aluede 2006 and Zindi 1994). Rusby et al (2005) also echoed the same sentiments when they list cruel criticism among some of the forms of harassment experienced by pupils.

According to table 1 the teachers also pointed out that nasty jokes, hitting and kicking and social exclusion were all very common among school pupils. However, there seems to be slight variations in the perceptions of the school heads about the forms of pupil to pupil peer harassment. While all the teachers agreed on the three most common forms of peer harassment, only $40 \%$ of the school heads viewed nasty jokes, hitting and kicking as forms of peer harassment. The other school heads $(60 \%)$ said they viewed these as child's play that was rough and not as any form of harassment. The school heads who viewed the afore stated forms of interaction as mere rough play argued that in the Zimbabwean culture rough play among children was acceptable as part of the process of growing up. These views by the Zimbabwean school heads are also in stark contrast with de Wet (2009)'s findings that educators in South Africa were aware that peer harassment among pupils was unacceptable and that they knew they had to prevent it. This divergence of views both at local and regional level among educators could be explained by the fact that while some people within our communities have embraced new ways of viewing relationships some still hold on to their old ways. This explanation is further emphasized by one school head who retorted that the term harassment was new in the Zimbabwean vocabulary and cautioned that teachers should not take every new idea that is foreign to the local culture as truth. The school heads' views further emphasized sentiments expressed in the Zimbabwean (2009) to the effect that peer harassment among pupils was a trivial issue in the Zimbabwean context. In light of the discussion above this researcher concludes that this state of affairs where the custodians of our children's safety feel that peer assessment is not an issue is worrisome. Efforts need to be made to conscientise all education personnel on the negative effects that harassment can have on pupils' learning and well being. The negative effects of peer harassment are well document in studies carried out in Europe and America.

The teachers were also asked to indicate whether they viewed pupil to pupil harassment as being serious, minor or not a problem at all. The results indicated further divergence in their perceptions with regards to the problem. The $65 \%$ who perceived peer harassment among pupils as being a serious problem argued that to them, the practice was a serious violation of human rights while the $25 \%$ who perceived it as a minor problem felt that pupils had to be exposed to situations that taught them that interactional process are not always smooth. Those who said it was not a problem at all said that being harassed was part of the process of growing up and so it was not a problem. The educators who perceived peer harassment as a serious problem concurred with those who perceived it as minor problem on the on the impact it had on discipline. They both agreed that it disrupted 
discipline.

The researcher further analyzed results to establish whether perceptions further differed according to the sex of the educator. The analysis indicated that there were differing perceptions according to the sex of the educators when it came to their views on spreading malicious rumors and sexual harassment as forms of peer harassment experienced by their pupils. $19.2 \%$ of the male respondents perceived spreading malicious rumors as a common form of peer harassment among pupils, while $57.69 \%$ of the female respondents agreed with the males. A very striking divergence occurred with regards to sexual harassment as a form of peer harassment. None of the male teachers perceived sexual harassment as a form of peer harassment while $41.66 \%$ of the female teachers viewed it as a common form of peer harassment. The striking differences in the perceptions of males and females with regards to sexual harassment as a common form of harassment can be attributed to the changing perceptions among women and girls with regards to their sexual rights. While some males have remained impervious to community programmes that relate to male and female sexual rights women have been more receptive hence the diverging perceptions.

\subsection{Conclusions}

The main conclusion of the study is that educators perceive certain behaviors among pupils as peer harassment but they have diverging perceptions of the forms and seriousness of the problem. The study also concludes that the differences in perceptions of peer harassment can be explained from three perspectives. The perceptions can be explained on gender lines, educator status and along cultural perspectives. On gender lines the study concludes that while both males and females concede that peer harassment is a problem among school pupils, females tend to think that it is a problem that is heavily rooted on sexual differences while the males think it is a problem that all pupils are exposed to in differing degrees. The cultural aspect is that educators' perceptions of peer harassment are influenced by their cultural views so that what educators in one community perceive as peer harassment might be considered as part of a normal interaction process in another community. The perceptions also seem to differ depending on the professional status of the educator. This study did not attempt to understand why the views of the teachers and the school heads differed so significantly in some instances but the researcher hypothesizes that may be the differences in ages of the school heads and the teachers as well as the amount of contact time they have with the pupils could be contributing factors to their diverging perceptions.

\subsection{Recommendations of the Study}

On the basis of the findings discussed above the study recommends that:

1) Further studies are carried out to establish compare pupils and teachers' perceptions of peer harassment among pupils. Such studies will enhance educators and stakeholders' appreciation of the complexity of the problem . This also will facilitate the development of a common understanding of the issue.

2) Government through Ministry of Education Sport and Culture comes up with a laid down policy that spells out what pupil behaviours should be categorised as peer harassment among school pupils and that Ministry of Education officials be proactive in ensuring that educators act in accordance with the policy on the prevention of harassment among school pupils. Coming up with a shared view of the forms of peer harassment would ensure that effective management structures are set up at school level to help educators in their efforts to deal with the problem.

3) Educators are concientised about current international perspectives on children's rights through workshops mounted by civic groups that deal with children's rights. This will bring them to the same perception levels with educators elsewhere so that they can then adopt best practices from educators around the world.

\section{References}

Aluede, O. (2011). Managing bullying problems in Nigerian secondary schools. Some Counseling interventions for implementation. The African Symposium, On line Journal of African Education Research, 11(1), 138-144. Retrieved form http://www.ncsu.edu/aern/TAS11.1/TAS11.1_Aluede.pdf

Aluedo, O. (2006). Bullying in Schools: A form of child abuse in schools. Educational Research Quarterly, 30(1), 37-49. Retrieved from http://www.eric.ed.gov/ERICWebPortal/search/detailmini.jsp?_nfpb=true\&_\&ERICExtSearch_SearchValue _0=EJ747619\&ERICExtSearch_SearchType_0=no\&accno=EJ747619

De Wet, C. (2005). The nature and extent of bullying in Free State secondary schools. South African Journal of Education, 25(2), 82-88. Retrieved from http://www.ajol.info/index.php/saje/article/view/25020/20692

De Wet, C. (2007). Educators' perceptions on bullying prevention strategies: South African Journal of Education, 
27(2) 191-208. Retrieved from http://www.ajol.info/index.php/saje/article/view/44140

Greef, P., \& Grobler, A. A. (2008). Bullying during the intermediate school phase: A South African study. Sage Journal of Childhood, 15, 127-138. Retrieved from http:// child.sagepub.com/content/15/1/127.pdf

Learn Without Fear Global Report. (2011). Using child -help lines to protect children from school violence. Retrieved form http://www.childhelplineinternational.org/assets/cms/File/Learn\%20Without\%20Fear\%20-\%20CHI-Plan\% 20Report $\% 20-\% 20$ for $\% 20$ online $\% 20$ use.pdf

Ministry of Education Sport and Culture. (2010). Schools directory. Harare: Government Printers .

Mitchelle, C., \& Kanyangara, P. (2005). Violence against children in and around schools in Ruwanda. Through the eyes of children and young people. Retrieved from http://payson.tulane.edu/gsdl-2.73/collect/mohnonve/archives/HASH966b.dir/doc.pdf

Nishina, A., Juvonen, J., \& Witkow, M. R. (2005). Sticks and stones may break my bones, but names will make me feel sick: The psychosocial, somatic, and scholastic consequences of peer harassment. Journal of Clinical and Child and Adolescent Psychology, 34(1), 37-48. Retrieved from http://www.njbullying.org/documents/nishinajuvonenwitkow2005-jccap.pdf http://dx.doi.org/10.1207/s15374424jccp3401_4

Rusby, J. C., Forrester, K. K., Biglan, A., \& Mezler, C. W. (2005). Relationships between peer harassment and adolescent problem behaviours. The Journal of Early Childhood Adolescence, 25, 453-477. Retrieved from http://jea.sagepub.com/content/25/4/453 http://dx.doi.org/10.1177/0272431605279837

Swart, E., \& Bredekamp, J. (2009). Non -Physical forms of bullying: Exploring the perspectives of grade 5 girls. South African Journal of Education, 29, 405-425. Retrieved from $\mathrm{http} / / /$ www.google.co.zw/\#hl=en\&sclient=psy-ab\&q=Swart+and+Bredkamp+Non+physical+forms+of+bull ying\&oq $=$ Swart + and + Bredkamp + Non + physical + forms + of + bullying\&aq $=f \& a q i=\& a q l=\& g s \_l=s e r p .3 \ldots 880$ 7.40197.0.41321.98.57.0.0.0.0.0.0.2.0...0.0.cBQu0024INA\&pbx=1\&bav=on.2,or.r_gc.r_pw.r_qf.,cf.osb\&f $\mathrm{p}=36 \mathrm{ead} 7 \mathrm{f} 7217 \mathrm{f5ea0} \& \mathrm{biw}=911 \& \mathrm{bih}=415$

The Zimbabwean. (2009). Shocking schools report on bullying and sexual harassment. Retrieved from http://www.thezimbabwean.co.uk/news/25501/-shocking-schools-report--beatings-bullying-sex-abuse.html

Troop Gordon, W. \& Quenette, A. (2010). Children's perceptions of their teachers' responses to students' peer harassment. Merril Palmer Quarterly, 56(3), 333-360. Retrieved from http://digitalcommons.wayne.edu/mpq/vol56/iss3/7 http://dx.doi.org/10.1353/mpq.0.0056

Zindi, F. (1994). Bullying at boarding school: A Zimbabwean study. Zimbabwe Journal of education, 51, 23-32. 